811.163.41'366.584.2

https://doi.org/10.18485/msc.2017.46.3.ch11

\author{
Милан В. СТАКИЋ \\ Филолошки факултет \\ Универзитета у Београду
}

\title{
ОБЛИЦИ ФУТУРА I У САВРЕМЕНОМ СРПСКОМ ЈЕЗИКУ
}

\begin{abstract}
Мада је у нашим граматикама савременог језика, од М. Стевановића до данас, готово устаљено мишљење да футур I има двојаке облике - сложене (ja ћу певати, доћи ћу) и просте (певаћу, певаћеш ...), у овом раду се доказује да тај глаголски облик може бити и јесте у савременом српском језику само сложени облик
\end{abstract}

Кључне речи: футур I, сложени облик, прости облик, граматичка основа, облички наставци, глаголски вид, дијахронија, савремено стање, правописна решења

У граматичкој литератури савременог српског књижевног језика најчешће ћемо, када је реч о морфолошком уобличавању футура I, прочитати да тај облик може бити сложен (нпр. Ми ћемо рећи. Сутра ћемо доћи. Наћи ћемо решење. Сви ћемо радити и сл.) и прост (нпр. Радићемо вредно. Причаћемо о томе. Јешћемо шта има и сл.). Да ли је баш тако? О томе ћемо расправљати у овом раду. Али да прво дамо кратак преглед или кратку историју овога питања.

Историја питања. За старословенски језик имало би и смисла и оправдања рећи да футур може бити исказан и простим и сложеним обликом. Тако и каже, нпр. Петар Ђорђић, који, макар и узгред, прави разлику између нашег (српског) и стсл. језика: „У нашем језику оба футура [мисли се на футур I и футур егзактни] су сложени глаголски облици. У старословенском језику је друкчије: егзактни футур гради се као и у нашем језику, а обични футур има двојаки облик: прости и сложени. Облик футура зависи од глаголског вида. Глаголи несвршеног или имперфективног вида имају сложени облик футура, а глаголи свршеног или перфективног вида по правилу имају прости облик футура.

\footnotetext{
"mstakic@open.telekom.rs
} 
Сложени облик футура гради се помоћу презента помоћнога глагола имамь и инфинитива глагола који се мења. На пример: можєта ин питн чашх њжжє аһъ имамь пнтн (Матеј 20.22)... чашу коју ћу ја пити.

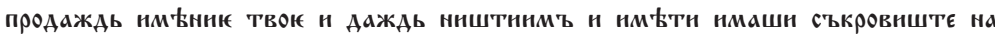
нєвєсе (Матеј 11.21) ... и имаћеш благо на небу.

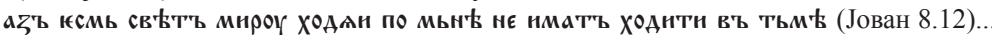
неће ходити по тами. [...].

Прости облик футура није посебан глаголски облик, формално то је презент, тачније: перфективни презент, који се у функцији правога футура налази и у источним и западним словенским језицима. На пример: поражж пастырірь и раднджтъ сА овьцА стада (Матеј 26.31) у руском језику: поражу пастыря и рассеются овцы стада; у нашем језику (у Вукову преводу): ударићу пастира и овце од стада разбјећи ће се" (Ђорђић 1975: 200).

Мада је презент перфективних глагола имао значење футура, П. Ђорђић истиче да се сложени футур градио и од глагола перфективног вида, додајући да се најчешће среће уз негацију, и то потврђује примерима из споменика:

„Примери без негације: прити во иматъ сынъ чмовъчьскъи въ слав' (Матеј $16.27)$ - јер ће доћи син човјечији у слави.

мъноSн во прндатть въ нма мок (Матеј 24.5) - јер ће многи доћи у име моје. огскышати имате Брани (Матеј 24.6) - чућете ратове.

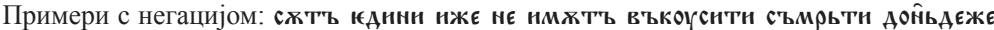
внаАтъ ц'ъсарิьствиє вожиє (Марко 9.1) - имају неки овдје који неће окусити смрти док не виде царство божје.

ни ґАннъ не въкоүснт моюњ вєчєрњ (Лука 14.24) - ни јеДан неће окусити моје вечере.

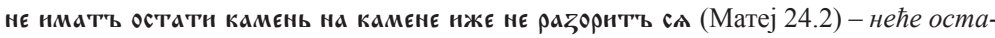
ти овдје ни камен на камену који се неће разметнути.

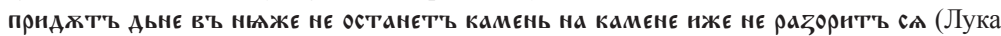

21.6) - доћи ће дани у које неће остати...

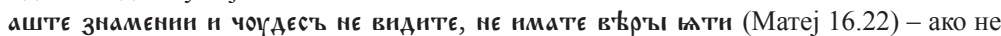
видите знака и чудеса не вјерујте (управо: нећете повјеровати).

аште вамъ рєк及, нє нмєте в'Њры (Лука 22.67) - ако вам кажем, нећете вјеровати" (Ђорђић 1975: 201).

Слично о овом облику пише и Светозар Николић, али не користи термине прост и сложен: „Изражава се [футур I] на два начина:

1) обликом презента перфективних глагола, нпр. азъ прншєАъ исц'Вањ и мт VIII 7 просі оу мне и дамъ ты Пс. 2а 16 ...

2) конструкцијом састављеном од инфинитива глагола који се мења и презента помоћног глагола, и то:

2а) Н.МА.МЬ, НМАШН ИТД.: НЕ Н.МА.ИЬ ПНТН ЮЖЕ ОТЪЬ СЕГО ПАОАА МОЗЪНААГО мт XXVI 29 Map....

2б) ХОШТЖ, ХОШТЕШН ИТД.: ЧТО ХОШТЕТЕ МН ААТН І АЗЪ ВА.ИЪ прЊда.Ме-н мт. XXVI 15 Map. ...

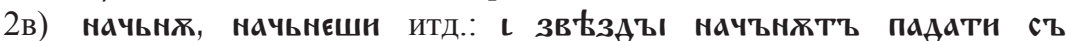
н(є)в (є)сє мк. XIII 25 ... и сл.” (Николић 1995: 214, 215). 
Дакле, опрезни Св. Николић не користи термине прости и сложени иако је могао јер облици презента перфективних глагола јесу прости облици, а конструкције састављене од инфинитива глагола који се мења и презента помоћних глагола јесу сложени облици. Они то јесу и према његовом објашњењу и подели глаголских облика. А ни тумачењу ни подели нема се шта приговорити:

„С обзиром на своје грађење - глаголски се облици деле на пр осте и сложене.

Пр ост и глаголски облици - који постају од основе различитим наставцима - јесу: презент, имперфекат аорист, супин и партиципи презента и претерита, активни и пасивни, као и партицип перфекта.

С л о же н и глаголски облици - који представљају конструкције састављене од именског облика глагола који се мења и одговарајућег облика помоћног глагола - јесу: перфекат, плусквамперфекат, футур, футур егзактни и потенцијал, као и облици за пасив" (Николић 1995: 175).

Сасвим је друга и друкчија ситуација у савременом српском језику. Пре свега, футур који се изражавао презентом перфективних глагола у штокавском говору потпуно је потиснут из употребе. Замењен је конструкцијом са $x о \hbar y$, која се првобитно употребљавала само уз несвршене глаголе. Конструкција са краћим (ненаглашеним, енклитичким) облицима глагола хтети у штокавским говорима, по А. Белићу, развија се пре писаних споменика и временом потискује друге начине образовања, оне са будем и имам (Белић 1999: 389).

Занимљиво је да Александар Белић за футур нигде не каже да може бити и „прост” глаголски облик - ни у Историји српског језика, видели смо, ни у својим средњошколским граматикама. У Граматици српскохрватског језика за први разред средњих и стручних школа А. Белић пише: „Како се гради

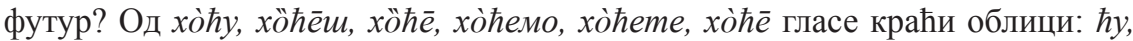
$\hbar е ш, ~ \hbar е, ~ \hbar е м о, ~ ћ е т е, ~ ћ \overline{e . ~ Т и ~ к р а ћ и ~ о б л и ц и ~ и л и ~ с е ~ д о д а ј у ~ к р њ е м ~ н е о д р е ђ е н о м ~}$ глаголском облику (nисат и ћу даје пúcaћy), те имамо пúcaћy, núcaћеш или се садашњем времену краћих облика од глаг. хтети додаје неодређени глаголски облик (у овом је случају неодређени глаголски облик потпун, неокрњен): jâ ћy núcати итд. ... Као што се из горњих примера види, оба се футура граде и од трајних и свршених глагола” (Белић 2000: 76).

Слично стоји и у Белићевој Граматици српскохрватског језика за трећи разред средюих и стручних школа: „Футур (будуће време) се гради од енкли-

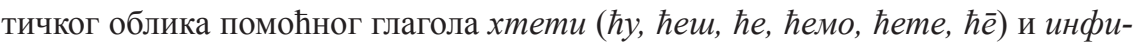
нитива (или презента са свезицом $\partial а$ ). Енклитички се глагол ставља испред инфинитива (или презента са $\partial a$ ) кад је у реченици субјекат исказан: jâ $\hbar y$ núcaтu или jâ $\hbar y$ да пúmе̄м или иза њега. Када се ставља иза инфинитива, тј. када субјекат засебном речју није исказан, онда сви глаголи - сем глагола на $\hbar u$ - имају облик на сугласник $m$ који испред $\hbar y$ испада; код глагола на $\hbar u-\hbar u$ се испред $\hbar y$ и осталих облика - чува: núcamћy - núcaћy, чѝнитћеш

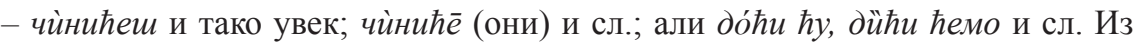
овога се види да се увек облик футура када се $m$ губи пише заједно са глаголом: núcaћy, но̀сићемо, прӓће и сл.; када је инфинитив потпун, пише се од- 
војено: дӥћи ћете и сл.” (Белић 2000: 228). - Дакле, нигде А. Белић за футур не користи термин прост глаголски облик. Зато је велико питање и, бар за нас, велика загонетка откуда тај термин (и његово тумачење) код Белићевог настављача Михаила Стевановића.

М. Стевановић у првом делу граматике Савремени српскохрватски језик (граматички системи и књижевнојезичка норма) каже ово: „Футур (будуће време) има двојаке облике и само једни од њих су сложени, и то од енклитичког облика презента глагола хтёти и инфинитива глагола који узимамо: jâ ћy пёвати, тй ћеш пёвати, оิн ће пёвати, мй ћемо пёвати, вй ћете пёвати, о̀ни ће пёвати и дйћи ћу, дйћи ћеш, дйћи ће, дйћи ћемо, дйћи ћете, дйћи ће....

Други облик футура је прост глаголски облик, као у примеру: пёваћy, пёваћеш, пёваће, пёваћемо, пёваћете, пёваће.

a) Футур је редовно сложен облик од глагола у којих се инфинитив завршава на -ћu, без обзира на то да ли помоћни глагол стоји испред или иза глагола који се мења. А сложен је футур и од глагола с инфинитивом на -ти ако је помоћни глагол испред облика инфинитива.

б) Међутим, ако инфинитив глагола на -ти долази испред помоћног глагола, футур је прост глаголски облик који се прави од скраћеног облика помоћног глагола хтети његовим срастањем с окрњеним обликом инфинитива. Пошто је тај облик постао једна реч, крајње $m$ од инфинитива испред $\hbar$ од помоћног глагола нестаје зато што се садржи у томе $\hbar$.

в) Али се и тада облик футура може писати и као сложен облик од два још несрасла саставна дела: пёват ћy, пёват ћеш, пёват ће, пёват ћемо, пёват ћете, пёват ће. (Треба знати само да се у једном делу или било каквом писменом саставу не могу мешати ова два начина писања футура)" (Стевановић 1970: 352).

Шта су за М. Стевановића прости, а шта сложени глаголски облици, схватићемо из напомене дате у вези са обрасцима промене глаголских облика по врстама (седам Стевановићевих врста, наспрам осам Белићевих):

\footnotetext{
„У горњим обрасцима промена дати су само прости глаголски облици, тј. облици од по једне речи, према којима имамо и сложене глаголске облике, у чији састав улазе облици глагола од по две или више речи" (Стевановић 1970: 336).
}

Овакво, крајње поједностављено, тумачење простих глаголских облика изазвало је и погрешно гледање на структуру неких облика футура $I$ - оних за које се тврди да су прости. Јер, ако је тачно - а то ни М. Стевановић не спори - да се прости глаголски облици граде од двеју основа (инфинитивне и презентске) помоћу наставака, а „већина глаголских облика има двојаке наставке: наставке за облик и личне наставке", питамо се од које основе би се градио прости футур - инфинитивне или презентске? Ни од једне, него - како и саิм М. Стевановић каже - „од скраћеног облика помоћног глагола хтети његовим срастањем с окрњеним обликом инфинитива”. А, с друге стране, ако је тачна (а морала би бити!) следећа констатација: „Све афиксал- 
не морфеме - префикси, суфикси и наставци за облик - по природи својој су в е з а н е (несамосталне) м о р фе м е зато што само са творбеним и граматичким основама са којима ступају у везу имају значење, било творбено, било граматичко, као и зато што се ни у реченици, ни у језику уопште не налазе самостално, изван тих веза" (Станојчић/Поповић 2008: 72) - ако ово прихватимо, јасно је да енклитички облици ћу, ћеш, ће, ћемо, ћете, ће не могу бити наставци јер се јављају и у слободној употреби, или још прецизније: никада се и не везују за глаголску основу.

Тако, дакле, футур I објашњава М. Стевановић. А као он или слично њему и скоро сви каснији настављачи.

У Енциклопедијском лексикону Мозаик знања (редактори и уредници Асим Пецо и Живојин Станојчић) - ни корак даље ни друкчије од М. Стевановића. И они кажу да футур може бити прост и сложен глаголски облик: „Futur kao prost gl. oblik tvori se od krnjeg oblika inf. i enkl. oblika prezenta gl. hteti, npr.: radiću (< radit-ću) ... Futur je redovno složen gl. oblik od glagola čiji se inf. završava na $c ́ i$ (reći $c ́ u$ ) i od gl. sa inf. na ti ako pomoćni glagol stoji ispred inf. (ja ću raditi). Međutim ako pomoćni gl. stoji iza oblika inf. na $t i$ - imamo dva slučaja: a) futur kao prost gl. oblik radiću (< radit-ću) i b) futur kao složen gl. oblik radit ću" (Мозаик знања 1972: 96) - Ако пођемо од краја, упоређујући paduћy (< padum-ћy) и радит $\hbar y$, видећемо да су оба облика идентична и по значењу и по функцији и по облику (и овај други се изговара $p a d u \hbar y)$, разлика је само у писању, а то је већ ствар Правописа, конвенције, и нема много везе са грађењем глаголских облика. Или има - за оне за које је прости глаголски облик „Глаголски облик састављен само од једне речи” и ништа више.

У Граматици српског језика за гимназије и средње школе боље су објашњени глаголски облици: „Прости глаголски облици граде се од презентске или од инфинитивне (аористне) основе додавањем на те основе наставака за облик (лични или нелични). ... Сложени глаголски облици јесу они који се састоје од помоћног глагола (јесам, бити или хтети) у личном (финитном) глаголском облику - обично енклитичком - и од одговарајућег глаголског придева (радног, трпног), односно инфинитива" (Станојчић/Поповић 2008: $118,124)$. - Иако је све ово тачно речено, ипак за футур I , идући за М. Стевановићем, кажу да је „сложени глаголски облик који се од свих глагола гради: везом облика презента помоћног гл. хтети, најчешће у његовом краћем облику ( $у$, ћеш, ће; ћемо, ћете, ће) и инфинитива глагола који се мења, по следећа два обрасца, ... - као сложени глаголски облик [jа] ћу певати ... - као прости глаголски облик певаћу, певаћеш ...

Прости облик футура I постао је додавањем енклитичких облика помоћ-

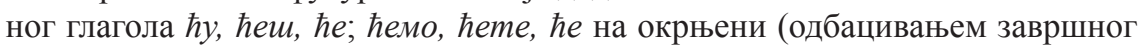
$-u)$ инфинитив, нпр., певат-: певат- + ћy, певат- + ћеш... $\rightarrow$ певаћу, певаћеш..., при чему је сугласник $m$ из окрњеног инфинитива испао (неутралисао се) јер се већ садржи у артикулацији африкате $\hbar "$ (Станојчић/Поповић 2008: 125). - И овде се ваља упитати: како се може градити прости глаголски облик и без основе (инфинитивне или презентске) и без наставака? Никако - намеће се одговор, јер нити је (окрњени) инфинитив основа нити су енклитички облици ћу, ћеш, ће; ћемо, ћете, ће наставци. 
Павица Мразовић каже да се футур I може градити од свих глагола (што је општепознато), да се гради од енклитичког облика презента помоћног глагола хтети и инфинитива глагола који носи значење (што нико не спори), ако испред глагола стоји заменица или нека друга реч, футур I , нпр. глагола писати гласи: jâ ћy núcaтu ... (и ово је тачно иако не каже да је то сложени глаголски облик), „ако потврдни облик футура I стоји сам или се њиме почиње реченица, енклитички облик се додаје на основу инфинитива (по одбијању наставка -mu): núcaћy, núcaћеш ..." (Мразовић 2009: 154, 155). - Ово последње захтева коментар. Енклитички облик се, дакле, не додаје на (окрњени) инфинитив, као код М. Стевановића, нити на супин, као код А. Белића, него „на основу инфинитива (по одбијању наставка -mu)”. „, Основа инфинитива” је ваљда исто што и „инфинитивна основа”, која је, по овој ауторки, код глагола који се у инфинитиву завршавају на -ћu или -сти најчешће једнака презентској, нпр. од глагола пѐћu, зе́nсти, ир́nсти инфинитивна основа која је једнака презентској гласи пек-, зеб-, ирn-. Наш став о добијању инфинитивне и презентске осноове, о њиховом међусобном односу и сл. - познат је (в. Стакић 2010: 96-104). Али кад би се и могла тако одредити (а не може!) инфинитивна основа, опет би се морало објаснити $c$ испред $\hbar y$, ћеш ... и његов алтернант $и$ у футуру глагола типа јешћy, cpewћy, озепшћу и сл. Тешко је, немогуће је прихватити њен нови и оригинални начин добијања „основе инфинитива” код глагола који се у инфинитиву завршавају на -ћu и -сти - одбијањем наставка -mu. Самим тим, део футура типа nucaћy, jewћy

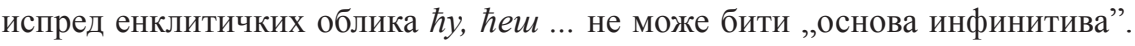
Истине ради, треба рећи да ова ауторка нигде не каже да футур I може бити и прости глаголски облик.

Аутори Предраг Пипер и Иван Клајн у граматици са претенциозним насловом Нормативна граматика српског језика кажу, попут многих других, да футур први има и просте и сложене облике. А шта подразумевају под терминима прости и сложени глаголски облици објаснили су мало раније: „Глаголски облици према степену сложености могу бити једночлани (нпр. читај), двочлани (нпр. читао је) или трочлани (био је читао). Једночлани глаголски облици називају се прости, а двочлани и трочлани - сложени.

Прости глаголски облици граде се додавањем наставака на презентску основу (нпр. пише-мо) или на инфинитивну основу (нпр. писа-х)" (Пипер/ Клајн 2013: 150). - Ово последње је тачно, само не зна се како би се овде уклопио прости футур кад он нема ниједну од ових двеју основа, а ни наставке схваћене као везане морфеме које се не јављају у слободној употреби. Они тај проблем решавају оригинално: основу не помињу, а испред енклитичких облика помоћног глагола хтети додају цртице и тако их „претварају” у наставке. Ево шта кажу: „У простим облицима футура I две глаголске коренске морфеме налазе се у истом сложеном граматичком облику у којем краћи облици другог глагола (помоћног глагола $x m e m u)$ носе граматичко значење будућег времена, нпр. разуме-ћy. Краћи облици помоћног глагола хтети у саставу једночланог футура I јесу следећи 


\begin{tabular}{|c|c|}
\hline ј е дн ин а & м н о ж и н а \\
\hline 1. л. $-\hbar y$ & $-\hbar е м о$ \\
\hline 2. л. -ћеш & $-\hbar е м о$ \\
\hline 3. л. $-\hbar е$ & -ће” (Пипер/Клајн 2013:173) \\
\hline
\end{tabular}

- Јесте оригинално, али да ли је и тачно? У простом облику футура I, по њима, нема основе него се „две глаголске коренске морфеме налазе у истом сложеном граматичком облику”. Ако и оставимо по страни могућу забуну како се у простом облику нађе сложени граматички облик, остају друга важна питања: да ли је прости футур сложеница?, у коју врсту сложеница бисмо га убројали (са спојним вокалом или без њега)?, да ли су у примерима разумећy, певаћу, размислићу и сл. две коренске морфеме (јер део испред ћу није корен)?, на шта се, на крају крајева, додају -ћy, -ћеш и сл.? Није тешко, разуме се, одговорити на ова питања. Футур први није сложена реч (сложеница) како

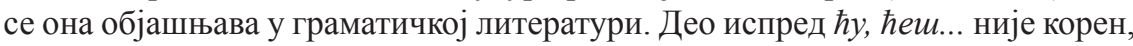
није ни основа (ни инфинитивна ни презентска), а шта јесте, видећемо касније у анализи. Не каже се додуше да су облици - $у$, -ћеш, -ће ... граматички наставци, али додавање цртице испред њих сврстава их неминовно у наставке (јер суфикси свакако нису). Морфеме не постају морфолошки наставци тако што ће им се додати цртице испред, него обрнуто - када морфеме стекну статус наставака, морају се обележити цртицама испред. А енклитички

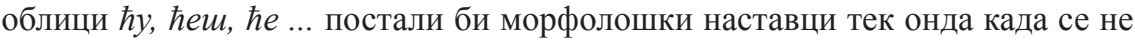
би употребљавали у слободној употреби (нпр. у сложеном футуру) и када би се изгубила свака веза са глаголом хтети (упор. наставке презента, аориста, имперфекта и свих других простих глаголских облика). На крају, чему служе напомене типа: „У футуру I треће лице једнине и треће лице множине увек су једнаки међу собом"? Нису никад једнаки јер је у трећем лицу једнине ће, а у трећем лицу множине ће̄ (упор. 3. л. једн. пёваће : 3. л. мн. пёваће̄).

Друкчије и од М. Стевановића и свих других које смо навели, о облицима футура I пишу Радоје Симић и Мирослав Николић.

Радоје Симић у својој Српској граматищи I не говори о футуру као простом глаголском облику. А пре тога, и уопштено, за глаголске облике каже: „Српски глаголи творе своје облике на више начина. Један је истоветан као и код других врста речи: на основу се додају наставци. Други је начин описан: обједињују се два или више облика у једну функционалну целину. Први су облици прости, други сложени, описни" (Симић 2001: 181). - Није, дакле, најважније и није једино важно за просте глаголске облике да се састоје од једне речи него да се у њима „на основу додају наставци”. Зато и није употребио термин прости облик за футур I, него то овако објашњава: „Када се помоћни глагол нађе у положају иза инфинитива, футур се изговара и пише на следећи начин:

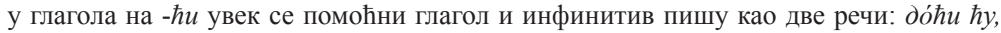
до́ћи ћеш...; рѐћи ћу, рѐћи ћеш...;

у глагола на -ти при изговору се изоставља крајње - $u$, а $m$ се губи испред $\hbar$, што се у писму често бележи, па се тај облик футура пише као једна реч: пúcaћy, за̀каснићу, дӓћy" (Симић 2001: 198). - А да ли се нешто пише као једна или као две речи предмет је право- 
писа а не граматике. Граматички би било погрешно, а то аутор има у виду, тврдити да је футур овога типа прост облик само зато што се пише као једна реч, за граматику је проста реч она у којој се на основу додају наставци.

Мирослав Николић слично али још одлучније доказује да не постоји прости облик футура I, да је он увек сложен глаголски облик. Ево шта он каже у својим универзитетским предавањима из Морфологије: „Иако се у нашим приручницима тврди да футур I може бити прост и сложен гл. облик, треба га сматрати само сложеним, јер се твори од двају других глаголских облика - инфинитива глагола који се мења и енклитичких облика презента помоћног глагола хтети. Ако је исказан субјекат (именицом или заменицом), онда иза њега долази енклитички облик + инфинитив неког глагола, а ако субјекат није исказан, онда код глагола на -ти имамо окрњени инфинитив (без финалнога -u) и енклитички облик презента помоћног глагола $x m e m u$, који се пише спојено, заједно са окрњеним инф. обликом, нпр.:

\begin{tabular}{|l|l|}
\hline \multicolumn{1}{|c|}{ једнина } & \multicolumn{1}{c|}{ множина } \\
\hline 1. л. ја̂ ћу ра́дити / ра́дићу & ми̂ ћемо ра́дити / ра́дићемо \\
\hline 2. л. тиิ ћеш ра́дити / ра́дићеш & ви̂ ћете ра́дити / ра́дићете \\
\hline 3. л. оิн (о̀на) ће ра́дити / ра́диће & о̀ни (òне) ће ра́дити / ра́диће \\
\hline
\end{tabular}

Одрично: не́ћy ра́dити, нёћеш ра́дити итд.

Облици типа páduћy настали су од радum+ћy, што одређеним фонетским променама даје páduћy. Наиме, елеменат гласа $m$ већ имамо у $\hbar$, па упрошћавањем сугласничке групе $m \hbar$ добијамо само $\hbar$. Једноставно речено, у paduћy од paдum-ћy имамо регуларну алтернацију $m \hbar / \hbar$. Резултати те промене огледају се код нас и у писму, дакле радићy, док код Хрвата имамо радит $\hbar y$, које се по правилу чита као радићy (ако не, како се понекад може чути, paдumu ћy). Да је футур I сложени глаголски облик и кад енклитика стоји иза инфинитивног облика, показују глаголи I врсте на -ћu, код којих, у књижевном језику, и у говору и у писму, имамо до́ћu ћy, pèћu ћy, опѐћu ћy се итд." (Николић ?: 27). - Као М. Николић, и ми сматрамо да је футур само сложен глаголски облик и покушаћемо то детаљно да образложимо. Али пре тога прегледаћемо и две хрватске граматике.

У Хрватској граматиции Е. Барић и групе аутора наилазимо прво на поједностављен опис глаголских облика: „Glagolski oblici od jedne riječi zovu se jednostavni, nes ložni ili sintetski, a od dviju i više riječi s loženi ili perifrastički” (Барић et al. 2005: 233). А о футуру глагола на -ти, што нас посебно занима, каже се: „Kada infinitiv na -ti dolazi prije oblika pomoćnoga glagola, infinitiv obično u govoru gubi svoj nastavak - $t i$ i provodi se jednačenje fonema prema mjestu tvorbe, ali se u pismu ispušta samo krajnje $-i$ : 


\begin{tabular}{|c|l|}
\hline Govori se & Piše se \\
\hline pítaću & pitat ču \\
\hline grǐš́u & grist ću \\
\hline
\end{tabular}

To nije nikakvo posebno pravilo za pisanje futura I, već se radi o pravilnim glasovnim alternacijama" (Барић et al:: 2005: 241). - Ми овде посебно истичемо две појединости: прво, не пише се футур никад као једна реч, али се изговара и, друго, ни за изговорну варијанту не каже се да је прости футур.

Слично глаголске облике описују и Јосип Силић и Иво Прањковић:

„Glagolski se oblici dijele na jednostavne i složene. Jednostavni su glagolski oblici oni koji se tvore od jednoga glagola, a složeni oni koji se tvore od dvaju ili triju glagola, od kojih su drugi i treći pomoćni. Pomoćni su glagoli bïti i htjëti” (Силић/Прањковић 2005: 58) - А за грађење футура I, поред осталог, кажу: „Kad se futur prvi tvori od infinitiva i nenaglašenih oblika pomoćnoga glagola htjëti, nenaglašeni oblici pomoćnoga glagola htjëti mogu dolaziti i iza infinitiva i ispred infinitiva. Kad dolaze iza infinitiva, infinitiv se rabi bez završnoga $i$ : (inf. čitati > čitat) čitat ću, čitat ćešs, čitat će, čitat ćemo, čitat ćete, čitat će. Tada se $t$ ispred oblika

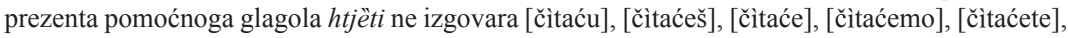
[čìtaće]” (Силић/Прањковић 2005: 91).

- И овде се тврди да се футур овога типа различито пише (нпр. читат ћy) и различито изговара: [чùmaћy]. Ово је за нас веома важно јер индиректно осветљава футур I у српском језику.

Анализа. Пођимо од неоспорних факата. Футур I (будуће време) гради се од презента помоћног глагола хтети и инфинитива глагола који се мења. Пуни облик презента помоћног глагола: хоћу, хоћеш, хоће, хоћемо, хоћете хоће употребљава се у посебним и ипак ретким ситуацијама: кад се наглашава (Хоћу радити, него шта ћу); када се изостави инфинитив, а из контекста се подразумева (Хоћеш ли студирати? Хоћу [студирати]) и испред упитне речце ли (Хоћеш ли устати рано?). Када се говори о морфолошкој структури футура I, мисли се на облике који су у најчешћој употреби, облике који се граде од енклитичког облика помоћног глагола хтети (ћy, ћеш, ће, ћемо, $\hbar е т е, ~ \hbar \bar{e})$ и инфинитива глагола који се мења. Из тога већ следи да је футур I сложени глаголски облик. Факат је и да се енклитички облици помоћног глагола могу наћи испред и иза инфинитива. Испред - када је исказан субјекат или неки други реченични конституент испред футура, а иза - када реченица почиње футуром. Додаћемо још и оно општепознато - инфинитив се у српском језику завршава на -тu, - $и$ и -сти. Све ово није спорно. А нису спорни ни облици футура када енклитички облици помоћног глагола долазе испред инфинитива: ( $\mathrm{Ja}$ ) ћу путовати; Сутра ћу пливати; Тихо ћу говорити и сл.

Разлике међу граматичарима су само када је реч о футуру код којег су енклитички облици иза инфинитива. Већина, видели смо, тврди да су ти облици прости кад се инфинитив завршава на -ти или -сти: читаћу, радићу, волећу, јешћy, namћеш, срешћеш и сл. Занимљиво је да нико од њих при класификовању глаголских облика не ставља футур у обе групе - просте и сложене - него само у сложене глаголске облике. А у анализи сложени су им 
само облици од глагола са инфинитивом на -ћu (peћu $\hbar y$, доћu ћеш, моћи ће и сл.), а прости су такви футури од глагола са инфинитивом - $т и$ и -сти (радићy, читаћеш, ручаће; сешћу, јешћеш, пашће и сл.). За нас су и ови последњи сложени. Тако мисли и М. Николић. А тако, много пре нас, пише и Тома Маретић, с тим што он и не одобрава писање облика мислићу и сл.: „Svi pisci rastavljaju enklitike od riječi s kojima ih akcent veže u jednu cjelinu, npr. govorio sam, kupila si, čudim se itd., pa tako je i Vuk činio, ali u futuru je on pisao: misliću, čuvaćeš, plešćemo itd. zato što on nikad nije pisao mislit, čuvat, plest držeći da su to dijalektizmi, a pravo književno da je misliti, čuvati, plesti itd. Pisati pak misliti ću, čuvati ćeš, plesti ćemo nije Vuk mogao jer takvih futurnih oblika nije on nikad čuo u dobrom štokavskom narodnom govoru. Ali kad svi pišemo opet ću (doći), dvaput ćeš (dati), kad ćeš (otići), sad ćemo (vidjeti), premda govorimo opeću, dvapućeš, kaćeš, saćemo, mislim da nije protivno fonetičkom pravopisu ni pisanje mislit ću, ̌̌uvat ćés ... osobito što se oblici mislit, ̌̌uvat često nalaze u narodnim pjesmama svih štokavskih govora; uostalom, pisanju misliću protivi se činjenica što se enklitike nikad ne pišu zajedno s riječju koja je pred njima (dakle ne govoriosam, čudimse, nego govorio sam, čudim se itd.)" (Maretić 1963: 44, 45). - Мислимо да ово последње поређење није адекватно јер се фонетски у изговору ништа не мења у примерима говорио сам, чудим се, а у футуру је неминовно долазило до алтернације $m: \varnothing$ и $c: u$ испред $\hbar$ (упор. paдum $+\hbar y$ $\rightarrow$ радићy, плест $+\hbar y \rightarrow$ плешћy). Остале су две могућности писања: онако како се изговара радићy, плешћy (јер није погодно * ради ћy, *nлеш ћy), или од чега потиче радum $\hbar y$, плест $\hbar y$. Српски правопис је усвојио ово прво, хрватски - оно друго. Само што ни писање ни изговор не показују праву слику граматичке, морфолошке структуре оваквих облика футура.

Подсетимо се: за М. Стевановића футур је увек сложен од глагола са инфинитивом на - $九$, а ако се завршавају на -mu, футур је сложен ако је инфинитив иза енклитичких глаголских облика, а прост ако инфинитив долази испред помоћног глагола. А онда следи занимљива констатација: „Али се и тада облик футура може писати као сложен облик од два још несрасла саставна дела: пёват ћy, пёват ћеш, пёват ће, пёват ћемо, пёват ћете, пёват ће. (Треба знати само да се у једном делу или било каквом писменом саставу не могу мешати ова два начина писања футура)" (Стевановић 1970: 352). - Да ли нису срасла та два дела (А Вук је још писао мислићу, чуваћеш, плешћемо ...) или је то био уступак западној, хрватској варијанти - питање је. Слично стоји и у Правопису из 1960. године: „... Ако помоћни глагол долази непосредно иза инфинитива глагола на -ти, онда се футур Ï пише на два начина:

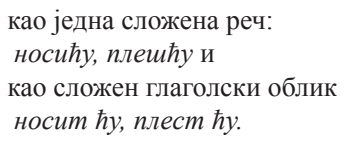

Сложени начин писања (носићy, плешћy) заснован је на фонетском принципу, а несложним начином писања чувају се у писму саставни делови овога глаголског времена (носит $\hbar y$, nлест $\hbar y$ ). Оба начина писања имају дугу 
традицију и своју оправданост, па се стога стављају као двострукост на читавом подручју српскохрватског језика према слободном избору самога писца. Дакако, у једном чланку, задатку, расправи или књизи може се употребити само један од споменутих начина, онај који одабере писац" (Правопис 1960: 83). - Те „двострукости” нема у Правопису из 2010: „Енклитички облици помоћних глагола спајају се само у футуру од глагола на -ти: занаћу, знаћеш, знаће, знаћемо, знаћете, знаће, трешћу, одвешћемо, чућеш итд. Од глагола на -ћи твори се само сложени футур: он ће доћи, доћи ће, изаћи ћу и сл." (Правопис 2010: 91). - Могли бисмо се упитати шта бй са „дугом традицијом” и „оправданошћу” двоструког писања. Пре ће бити да је то био договорени уступак хрватској пракси писања овог глаголског облика. Али то није ни важно и ми се тим питањима не бисмо посебно бавили да не сматрамо да је управо писање разлог што су М. Стевановић и сви који су ишли за њим говорили о простом футуру. А ми и даље, и са још већим уверењем, тврдимо да нема простог футура, постоји само футур као сложени глаголски облик.

У Правопису Милорада Дешића (и у старијем издању из 1994. г. и у новом издању из 2015. г.) не квалификује се футур ни као сложен ни као прост облик, али се веома прецизно и тачно описује како се пише: „Писање футура нешто је сложеније. Наиме, његови делови пишу се растављено ако се помоћни глагол ( $у$, ћеш...) налази испред инфинитива на -ти: ja ћу купити, ти ћеш трести, а састављено кад је помоћни глагол иза таквог инфинитива: кy$n u \hbar y$, mрешћеш. Футурски облици глагола на -ћu увек се пишу одвојено, без обзира на редослед њихових делова: ја ћу наћи и наћи ћу, он ће поћи и поћu $\hbar е$ " (Дешић 2015: 106). - Овакво представљање писања футура I у суштини се подудара са нашим ставом о његовој морфолошкој структури. Наиме, ми сматрамо - и то је основна идеја и циљ овога рада - да је футур I сложени глаголски облик састављен из два засебна дела - инфинитива (или супина) глагола који се мења и енклитичких облика презента помоћног глагола $x m e-$ $m u$; ти делови се у нашем књижевном језику и по нашем Правопису пишу одвојено кад се енклитички облици налазе испред инфинитива, а кад стоје иза инфинитива, опет се пишу одвојено ако се тај инфинитив завршава на -ћu, а састављано ако се завршава на -ти или -сти.

А сада - о саставним деловима сложеног футура. Овај глаголски облик састоји се, рекосмо, од инфинитива и енклитичких облика презента помоћног глагола хтети. Енклитички облици су увек исти: ћy, ћеш, ће, ћемо, ћете, $\hbar \bar{e}$, без обзира на позицију у оквиру футура (да ли стоје испред или иза инфинитива). А није тако одувек било. Некада се футур свршених глагола изражавао презентом, а футур несвршених глагола - конструкцијама састављеним од презента глагола имам, хоћу и буду и инфинитива глагола који се мења. У штокавским говорима, већ пре писаних споменика, развија се нарочити облик за футур од скраћених облика презента глагола $x m$ Јти и инфинитива. Та ће конструкција временом потиснути из употребе све друге начине образовања футура - и конструкције са будем и имам и перфективни презент у функцији футура (в. Белић 1999: 389). Што се тиче инфинитива, сви се слажу да он у оквиру футура увек има пуни облик ако се налази иза енклитичких 
облика помоћног глагола, а кад стоји испред тих енклитика, има пуни облик само ако се инфинитив завршава на - $и$ и пише се одвојено од енклитика, а ако се завршава на -ти или -cmu, јавља се у облику без крајњег - $и$ и пише се, по нашем фонетском Правопису, сатављено са енклитикама, при чему се јављају његови аломорфи изазвани морфонолошким алтернацијама $m: \varnothing$ и $c$ $: u$ испред $\hbar$ ( $m: \varnothing$ у нпр. радићy < paдumћy< paдum $+\hbar y ; m: \varnothing, c: u$ у нпр. jeuћy $<$ jechy $<$ jecmhy $<$ jecm $+\hbar y)$.

Тај облик инфинитива, без крајњег -u, М. Стевановић назива „окрњени облик инфинитива", а по А. Белићу, такви облици (без $u$ ) почињу се у нашим споменицима употребљавати од XIV века, то су стари облици супина, који су се у штокавским говорима ограничили на футур: купит-ћу што је дало купићу и сл.

Могу ли облици футура типа paдuћy, куnuћy, jeuћy и сл. бити прости глаголски облици? Да - за оне који поједностављено тумаче такве облике, изједначују просте и једночлане облике (састоје се од једне речи). Не - за нас и за све оне који просте глаголске облике схватају као синтезу глаголске основе (презентске или инфинитивне) и обличких наставака. Конкретно речено, у облицима paдuћy, куnuћy, певаћy, знаћу и сл. део испред енклитике (радu-, купи-, пева- и сл.) није инфинитивна основа иако се код тих и неких других глагола облички са њом подудара, оне који би размишљали у том правцу демантују облици тог истог футура од глагола чији се инфинитив завршава на -сти: срешћy, nawћy, јешћy, плешћу и др. (инфинитивна основа тих глагола је срет-, пад-, јед-, плет- и др.). Ваља објаснити, разуме се, фонему и, која се не може добити од $m(\partial)$ испред $\hbar$, за такву гласовну промену наука о језику не зна. То $u$ потиче од $c$ једначењем сугласника по месту творбе (испред $\hbar)$ и то није спорно, а $c$ налазимо само у инфинитиву (срести, пасти, јести, плести и др.). И још нешто - не одбацује се у футуру наставак -ти од инфинитива јер оно што остаје није морфема (упор. *cpec-, *nac-, *jec-, *nлес- и сл.), него се за футур узима стари супин, подударан са инфинитивом без крајњег -u, а његови аломорфи среш-, naw-, јеш-, плеш- и сл. добијени су фонетским путем, после неминовног губљења $m$ испред $\hbar$ и једначења по месту творбе сугласника $c$ испред $\hbar$ или после алтернација $m: \varnothing$ и $c: u$.

Енклитички облици у примерима футура во̀лећу, во̀лећеш, во̀леће, во̀лећемо, во̀лећете, во̀леће̄ и сл. нису морфолошки наставци иако се налазе позиционо на месту наставака. Да би постали наставци, морали би изгубити самосталну употребу и семантичку, обличку и сваку другу везу са глаголом xтети. То су посебни чланови сложеног футура који се у оваквим облицима, по нашем Правопису, пишу састављено са аломорфима инфинитива (супина). Додајмо и то да алтернације $m: \varnothing$ и $c: u$ нису се јавиле зато што се овакав облик футура пише као једна реч, јер по хрватском Правопису пише се са две речи а изговара као и код нас: пише се numam $\hbar y$, грист ћy а изговара ce númaћy, грйшћy. Битно је, дакле, не да ли се пише као једна или као две речи него то што инфинитив (супин) и енклитички облици презента глагола

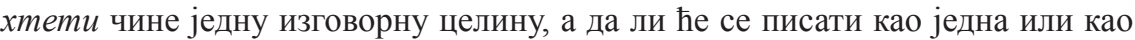
две речи није предмет граматике, него правописа. 
На крају, још неколико речи о сложеним облицима футура од глагола чији се инфинитив завршава на -ћu. Сви се слажу у једном: футур од таквих глагола увек је сложен: $а$ ћу рећu и рећи ћy. То је тачно, а видели смо да је и код свих осталих глагола футур увек сложен облик. Сви такође мисле да је футур оваквих глагола увек двочлан, тј. да се инфинитив и енклитички облици увек пишу одвојено. И то је тачно, ако се мисли само на књижевни језик. У народним говорима и тај се футур може чути као једна реч. Један пример нашли смо код А. Белића: „Треба напоменути да се у већини футурских облика находи краћи облик инфинитива: $n u c a(m) \hbar y$, чува(m) $\hbar y$ итд. поред доћи ћy итд. (исп. и доћу)" (Белић 1999: 444). Понеки пример наћи ћемо и у Кочићевим делима, разуме се, у говору ликова: „Сад ће те двије године протећи к’о ладна вода, п' онда, ко си, ти си! Доћ 'ће он, болан! (Туба 45); Столе мој, крви моја, тражићемо ми своју пра́ву. Ић' емо ми у Беч (Гроб Слатке душе 75); Дети, Дојто, доиес [доћеш] ти по' свабину томанду (Јуре Пилиграф 118); Ама, то није у најмању руку у реду да рече један рећемо каз'ти, царски службеник (Јазавац пред судом 172)" (Петар Кочић, Сабрана дјела, Књига I, Сарајево 1967). - У штампању примећују се интерванције, највероватније лекторске, нпр.: доћ'ће [доће] (тешко је замислити да Кочићеви јунаци говоре доћ ће), или $u \hbar ' е м о$ (са апострофом којему ту никако није место).

Много више примера нашли смо у монографији Драгољуба Петровића О говору Змијања: „Футур глагола на - $и$ доследно се појављује у формама са редукцијом ове морфеме: рѐћемо, на́ћемо, ѝћемо, рѐће да е излудио, нáћe вас, dó $y$ ја у кућу, дóћe до поноћи". Додајмо томе и два примера из приложених Текстова - Згрेнемо жйто око стӧжера, pèћемо ; ... òceћy му глаิву док на̀љезе̄м ... (Петровић 1973: 172). - Примери су поуздани, али објашњење да се футур глагола на -ћи доследно појављује са редукцијом „ове морфеме”, требало би изменити те да гласи са редукцијом тога завршетка јер - $и$ у инфинитиву није морфема него фонолошки завршетак.

Нашли смо подоста примера и код Милорада Дешића, у његовој дисертацији Западнобосански ијекавски говори. Иако у одељку Морфологија М. Дешић не говори посебно о футуру I уопште, па самим тим ни о футуру глагола са инфинитивом на - $и$, у обимном материјалу датом као илустрација

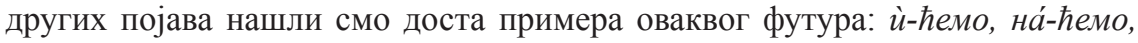

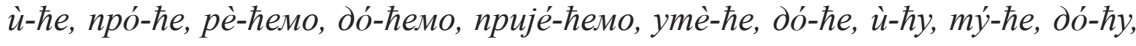
до́-ћеш, òсје-ће. Додајмо још неколика примера из Дешићеве грађе: на́ћемо

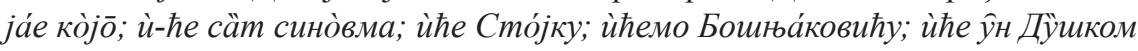
у Нӧвй Са̂т; ѝћемо ѝскати да нас припо̀могнӯ; ѝће пола́гати; бо̀й се по̀бјеће; бò̀ ce mýћe га (Дешић 1976: 187).

Иако су сви примери из народних говора, иако овај облик футура није прихваћен у књижевном језику, ваља га забележити и објаснити. За разлику од футурских облика радићy, cpemћy, код којих имамо алтернације $m: \varnothing$ и $c$ : $\hbar$, овде имамо своје врсте хаплологију, тј. губљење завршетка - $и$ испред енклитичких облика $\hbar y, \hbar е ш . .$, који почињу гласом $\hbar$, са, вероватно, аналошким наслањањем на футуре типа радићу, jeшћу и др. 
Закључне напомене. Облици футура у савременом српском језику су увек сложени облици састављени од инфинитива и презента помоћног глагола хтети. Пуни облици презента глагола хтети ређе се користе у футуру - само кад се посебно наглашавају и кад се нађу испред упитне речце ли. Најчешће је футур, дакле, перифрастична конструкција састављена од скраћених, енклитичких облика презента помоћног глагола хтети: $\hbar y, \hbar е m$, $\hbar e, \hbar е м о, ~ \hbar е т е, ~ \hbar \overline{e ~ и ~ и н ф и н и т и в а ~ г л а г о л а ~ к о ј и ~ с е ~ м е њ а . ~}$

Некада је футур зависио од глаголског вида - код свршених глагола у функцији футура употребљавао се презент, а код несвршених глагола поред $x о \hbar y$, употребљавали су се још и имам и будем са инфинитивом глагола који се мења.. Времном су облици са глаголом хтети уз инфинитив потиснули из употребе све остале облике футура - и презент перфективних глагола у улози футура и све друге помоћне глаголе уз инфинитив глагола који се мења.

Футур I у савременом српском језику не може бити прости глаголски облик јер се сви прости глаголски облици граде од презентске или инфинитивне основе и наставака за облик, а једночлани футури (двочлани ни за кога нису спорни) немају ни једно ни друго: у примерима радићу, куnићу, срешћy, nawhy и сл. део испред енклитичких облика није инфинитивна основа (иако се почесто облички са њом подудара), што поуздано потврђују глаголи на сти и њихов једночлани футур: јешћу, срешћеш, пашће, плешћемо, сешћете, бошћ $\bar{e}$ - инфинитивна основа ових глагола није *jem-, *cреш-, *nаш-, *nлеш-

, *сеш-, *бош- него јед-, срет-, пад-, плет-, сед-, бод-. Никаквим чаробним штапом, никаквом гласовном променом не могу $m$ и $\partial$ прећи у $c(>m)$. Све ово и кад оставимо по страни сасвим логично питање: откуд инфинитивна основа у грађењу будућег времена. С друге стране, ни енклитички облици ћy, $\hbar е ш, \hbar e, \hbar е м о, ~ \hbar е т е, ~ \hbar \overline{e ~ н и с у ~ м о р ф о л о ш к и ~ н а с т а в ц и ~ ј е р ~ н и с у ~ в е з а н е ~ м о р ф е м е ~}$ (које само кад су додате на основу имају граматичко значење) него имају и слободну употребу и у њима се јасно виде скраћени, енклитички облици презента глагола хтети, што се не може рећи за морфолошке наставке простих глаголских облика. Облик футура (једночлан или двочлан) не мења, дакле, сложеност, дводелност њихову - увек су састављени од аломорфа инфинитива глагола који се мења и енклитичких облика помоћног глагола хтети.

Граматички гледано, футур је увек сложен и двочлан глаголски облик, а у писању његов формални облик (једночлан или двочлан) зависи од распореда његових делова, од завршетка инфинитива и од правописне конвенције. Ако је инфинитив иза енклитика, увек је двочлан. Ако је испред енклитика, двочлан је кад се завршава на -ћu, а кад се завршава на -ти и -сти, једночлан је (не и прост!), по нашем правописном решењу, по хрватском Правопису и тада је двочлан. 


\section{ЛИТЕРАТУРА}

Барић и др. 2005: Eugenija Barić, Mijo Lončarić, Dragica Malić, Slavko Pavešić, Mirko Peti, Vesna Zečević, Marija Zinka, Hrvatska gramatika, Zagreb: Školska knjiga.

Белић 1999: Александар Белић, Историја српског језика, Изабрана дела Александра Белића, том 4, Београд: Завод за уџбенике и наставна средства.

Белић 2000: Александар Белић, Граматике. О граматикама, Изабрана дела Александра Белића, том 12, Београд: Завод за уџбенике и наставна средства.

Дешић 1976: Милорад Дешић, Западнобосански ијекавски говори. Београд: Институт за српскохрватски језик.

Дешић 2015: Милорад Дешић, Правопис српског језика, Београд: Klett.

Ђорђић 1975: Петар Ђорђић, Старословенски језик, Нови Сад: Матица српска.

Маретић 1963: Tomo Maretić, Gramatika hrvatskoga ili srpskoga književnog jezika, Zagreb: Matica hrvatska.

Мозаик знања 1972: Asim Peco i Živojin Stanojčić (redaktori i urednici), Srpskohrvatski jezik : Enciklopedijski leksikon Mozaik znanja, I, Beograd: Interpress.

Мразовић 2009: Pavica Mrazović u saradnji sa Zorom Vukadinović, Gramatika srpskog jezika za strance, Sremski Karlovci - Novi Sad: Izdavačka knjižarnica Zorana Stojanovića.

Николић: Мирослав Николић, Предавања из Морфологије - Глаголи [скрипта за студенте].

Николић 1995: Светозар Николић, Старословенски језик I, Београд: Требник.

Петровић 1973: Драгољуб Петровић, О говору Змијања, Нови Сад: Матица српска.

Пипер/Клајн 2013: Предраг Пипер и Иван Клајн, Нормативна граматика српског језика, Нови Сад: Матица српска.

Правопис 1960: Правопис српскохрватскога књижевног језика са правописним речником, Нови Сад: Матица српска

Правопис 2010: Митар Пешикан, Јован Јерковић и Мато Пижурица, Правопис српскога језика, Нови Сад: Матица српска.

Силић/Прањковић 2005: Josip Silić i Ivo Pranjković, Gramatika hrvatskoga jezika za gimnazije i visoka učilišta, Zagreb: Školska knjiga.

Симић 2001: Радоје Симић, Српска граматика I. Увод, фонологија, морфологија, Београд: МХ Актуел.

Стакић 2010: Милан Стакић, Морфо(но)лошке теме, Београд: Друштво за српски језик и књижевност Србије.

Станојчић/Поповић 2008: Живојин Станојчић и Љубомир Поповић, Граматика српскога језика за гимназије и средње школе, једанаесто, прерађено издање, Београд: Завод за уџбенике.

Стевановић 1970: Михаило Стевановић, Савремени српскохрватски језик I, Београд: Научна књига. 
Милан В. Стакић

Milan V. Stakić

THE FORMS OF FUTUR I (FUTURE SIMPLE TENSE) IN SERBIAN

Summary

Despite the fact that contemporary grammars of Serbian tend to identify both complex forms such as ja ću pevati, doći ću and simple forms such as pevaću, pevaćeš as Futur I (Future Simple Tense) in this paper, we argue that in contemporary Serbian Futur I can only be seen as a complex verb form. 